\title{
Analisis Metode Pembelajaran yang dapat digunakan pada Pembelajaran PAI
}

\author{
Subhan $^{1}$, Ulfah Novianti ${ }^{2}$ \\ ${ }^{1}$ MTsN 4 Tebo, Jambi, Indonesia \\ ${ }^{2}$ Pendidikan Guru Sekolah Dasar, Universitas Jambi, Jambi, Indonesia
}

\begin{tabular}{l}
\hline \hline Article Info \\
\hline Article history: \\
Received Mar 15, 2020 \\
Revised Mei 7, 2020 \\
Accepted Jul 10, 2020
\end{tabular}

\section{Keywords:}

Analisis

Metode Pembelajaran

Pembelajarn PAI

\begin{abstract}
ABSTRAK
Tujuan penelitian: Adapun tujuan dari penelitian ini untuk mendeskripsikan pentingnya penggunaan metode dalam pembelajaran, selain itu juga untuk mendeskripsikan metode-metode yang dapat digunakan dalm pembelajaran PAI, karen apembelajaran PAI merupakan pendidikan yang sangat penting untuk ditanamkan kuat dari dir peserta didik.
\end{abstract}

Metodologi: Penelitian ini menggunakan metode kualitatif tipe kajian kepustakaan, yang artinya menggunakan berbagai sumber ilmiah untuk mendeskripsikan berkaitan dengan analisis metode pembelajaran yang dapat digunakan pada pembelajaran PAI. Analisis yang digunakan analisi isi atau konten.

Temuan utama: Setelah melakukan analisis berbagai sumber, seperti jurnal ilmiah dan artikle maka ada beberapa metode yang dapat digunakan dalam pembelajaran PAI, seperti PBL, Numbered head together, pembelajaran multikultural, tutor sebaya, market place, dan lain sebaainya.

Keterbaruan penelitian: Keterbaruan dari penelitian ini yaitu dapat menggunakan atau menerapkan metode yang layak digunakan untuk pembelajarn PAI.

This is an open access article under the $\underline{C C B Y-N C \text { license }}$

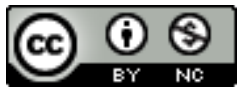

\section{Corresponding Author:}

Ulfah Novianti,

Fakultas Keguruan dan Ilmu Pendidikan, Universitas Jambi, Jambi, Indonesia

Email: ulfahnov.77@gmail.com

\section{PENDAHULUAN}

Pendidikan merupakan upaya untuk memberikan pengajaran kepada peserta didik disekolah dengan harapan peserta didik dapat meningkatkan perkembangan kognitif, afektif dan psikomotor peserta didik. Pengajaran tersebut dilakukan dengan proses yang panjang karena menyampaikan banyak sekali ilmu kepada peserta didik. Pembaharuan-pembaharuan dalam bidang pendidikan terus diakukan dengan harapan penyelengaraannya semakin efektif dan memberikan dampak positif bagi pendidikan Indonesia. Melalui pendidikan yang efektif diharapkan dapat mencetak generasi penerus bangsa yang dapat mengembangkan dan memajukan negara Indonesia. meskipun beberapa pembaharuan dalam bidang pendidikan telah banyak dilakukan seperti pergantian kurikulum dan pengadaan sarana dan prasarana namun indonesia masih pada tingkat rendah pada bidang pendidikannya. Pendidikan di Indonesia tergolong kedalam tingkat yang rendah [1]. Penyebab rendahnya pendidikan di Indonesia tentu beragam, mulai dari rendhanya kualifikasi dari tenaga pendidik, kurangnya sarana dan prasarana dan ketidak mampuan menggunakan kurikulum. Meskipun terdapat beberapa kekurangan namun tetap saja pendidikan di inonesia harus diselenggarakan. Terutama adalan pendidikan agama islam, pendidikan agama islam diharapkan mampu memperkuat sikap seseornag 
peserta didik, diyakini jika sikap peserta didik sudah baik maka pembelajaran lainnya akan menyusul menjadi baik, sehingga sangat penting sekali pembelajaran pendidikan agama islam.

Pendidikan agama islam merupakan upaya membimbing dan mengarahkan peserta didik untuk berprilaku dengan baik sesuai dengan ajaran agama islam [2]. Ajaran agama islam memberikan dampak yang positif pada perkembangan sikap seseorang, karena pada pendidikan agama islam diajarkan akiah akhlak yang dapat mebentuk peserta didik menjadi seseorang yang memiliki etika. Pendidikan agama islam merupakan pemberian bimbingan dan arahan agar peserta didik memiliki kepribadian yang baik [3]. Dan mampu menjadi generasi penerus bangsa, generasi penerus bangsa yang baik adalah yang mampu memberikan kontribusinya dalam perkembangan bangsa dengan tidak melakukan kegiatan yang menyimpang dan diluar aturan bangsa indonesia. sehingga generasi yang diharapkan adalah memiliki jiwa yang mencerminkan jiwa keislaman. Jiwa muslim yang sejati dapat ditanamkan sejak dini kepada peserta didik melalui pendidikan agama islam [4]. Pendidikan agama islam bertujuan untuk menumbuhkan keimanan dan ketakwaan seorang peserta didik kepada allah SWT [5]. Karena tujuan dari pendidikan agamam islam dirasa sangat lah penting, lalu yang harus diupayakan adalah pengajaran yang efektif kepada peserta didik yang dilakukan oleh guru.

Guru merupakan seseorang yang memiliki peran penting dalam pengajaran kepada peserta didik. Sudah seharusnya guru memiliki kompetensi yang dapat membuat pembelajaran menajdi lebih menarik dan memungknkan peserta didik untuk memahami pembelajaran yang diberikan serta tidak memiliki kesulitan dalam belajar. Guru harus mempuyai cara yang unik dan menarik perhatian peserta didik dalam proses pembelajaan [6]. Selain itu, Guru perlu memiliki pemikiran inisiatif dan kreatif dalam melakuakn pembelajaran PAI [7].Kemudian penggunaan strategi yang tepat dalam proses pembelajaran PAI akan mempengaruhi keaktifan dan pemahaman dari peserta didik [8]. strategi yang diperlukan adalah pemilihan model dan metode pembelajaran yang tepat dalam mengejarkan pendidikan agama islam. Karena Penggunaan metode dalam pembelajaran sangat penting guna meningkatkan motivasi belajar peserta didik [9]. Motivasi belajar peserta didik akan mempengaruhi kepada tingkat keberhasilan dari belajar peserta didik. Apabila hasil belajar peserta didik tinggi maka mutu pendidikan juga akan meningkat.. Mengingat bahwa Mutu pendidikan pada saat pembelajaran akan meningkat apabila didukung oleh metode yang tepat [10]. Penggunaan metode yang tepat diharapkan dapat meningkatkan hasil belajar peserta didik, sehingga mutu pendidikan indoneisa meningkat. Mutu pendidikan perlu ditingkatkan supaya melahirkan generasi penerus bangsa yang berwawasan luas [11]. Peningkatan mutu pembelajaran salah staunya adalah peserta didik bisa berfikir kritis, upaya agar berfikir kritis adalah penggunaan bahan ajar yang menggunakan teks menarik [12].

Pada kenyataannya, Indonesia masih berada pada Mutu pendidikan yang rendah karena dalam pembelajaran masih menggunakan pembelajaran tradisional [13]. Pembelajaran tradisional seperti biasa yang dilakukan adalah penggunaan metode ceramah. Seharusnya guru menggunakan metode yang bervasriasi supaya peserta didik tidak bosan dalam pembelajaran. jika peserta didik sudah bosan dalam mengikuti proses pembelajaran, maka yang akan terjadi adalah kesulitan belajar pada pemahman materinya. Seharusnya peserta didik tidak hanya mendengarkan dalam proses pembelajaran, namun ikut aktif dalam proses pembelajaran. karena Perkembangan ilmu seseorang terjadi karna adanya kebiasaan membaca, menulis dan disukusi [14].

Dengan adanya mutu pendidikan yang rendah karena kurang bervariasinya penggunaan metode pembelajaran pada materi PAI, maka penulis tertarik untuk menganalisi mengenai metode yang dapat digunakan dalam pembelajaran agama islam, penelitian ini tentu bertujuan untuk mendeskripsikan metode apa saja yang dapat digunakan dalam pembelajaran pendidikan agama islam, dan dirasa memiliki keefektifan yang tinggi. Setelah hasil analisis dilakukan, kemudian dideskripsikan dalam kalimat-kalimat kemduian diharapkan tulisan ini dapat dimanfaatkan oleh guru PAI yang akan memebrikan pengajaran materi pendidikan agama islam kepada peserta didik diskeolahnya masing-masing.

\section{METODE PENELITIAN}

Upaya menganalisis metode yang dapat digunakan dalam pembelajaran pendidikan agama silam, Peneliti menggunakan peneltian kualitatif. Metode kualitatif merupakan metode yang digunakan agar endapatkan wawasan baru mengenai suatu hal yang terjadi secara alamiah dan apa adanya [15]. Wawasan tersebut biasanya berbentuk fenomena yang terjadi sehingga dapat dideskripsikan kedalam sebuah kalimat yang memungkinkan orang lain untuk membaca dan memanfaatkannya. Hal tersebut diperjelas oleh Safrizal, 2020, bahwa Penelitian kualitatif merupakan suatu upaya menggambarkan kondisi lapangan yang terjadi kemudian dideskripsikan [16]. Namun karena pada saat ini sedang berada pada masa covid-19 sehingga membuat peneliti melakukan penelitian menggunakan metode kajian kepustakaan. Metode yang digunakan adalah metode kajian kepustakaan, kajian kepustkaan adalah memfokuskan pengumpulan literatur yang berkaitan dengan topik permasalahan [17]. 
Permasalahan dalam penelitian ini adalah penggunaan cara pembelajaran secara tradisional sehingga dibutuhkan suatu solusi dan pemecahan masalah untuk membuat pembelajaran lebih aktif dan efektif, dengan beberapa hal pertimbangan dirasa perlu dan penting untuk menganalisi berbagai macam metode yang dapat digunakan dalam proses pembelajaran. analisi data yang digunakan dalam penelitian ini adalah analisis isi, peneliti akan menganalisis beberapa sumber yang dapat digunakan terkait dengan analisis metode dalam pembelajaran pendidikan agama islam.

\section{HASIL DAN PEMBAHASAN}

Berikut merupakan hasil analisis mengenai metode yang dapat digunakan dalam pembelajaran pendidikan agamam islam :

\subsection{Joyfull Learning}

Penggunaan metode joyfull learning membuat peserta didik senang dan tidak tegang dalam pembelajaran [18]. Joyfull learning sendiri adalah pembelajaran yang menyenangkan. Pembelajaran menyennagkan bukan diartikan sebagai pembelajaran yang banyak tertawa terbahak-bahak, namun pembelajaran yang memiliki daya tarik untuk melakukan pembelajaran dengan penuh semangat. Pembelajaran menggunakan joyfull learning perlu mendesain suatu pembelajaran yang tidak membosankan dan membuat siswa aktif dalam pembelajaran seeperti menggunkan game, kuis, dan kerja tim, dengan hal tersebt peserta didik akn berkeplorasi dan berkerjasam dengan temannya hingga menciptakan pembelajaran yang tdai membosankan.

\subsection{PBL (Problem Based Learning)}

Terdapat pengaruh positif terhadapa hasil belajar peserta didik pada mata pelajaran PAI menggunakan model pembelajaran Problem based learning [19]. Pembelajaran menggunakan PBL ini adalah terdapat suatu masalah yang nyata, kemudian peserta didik diinta memiliki pemikiran yang kritis kemudin mencoba mencari sousi dari permasalahan yang ada. Pada pembelajaran ini lebih menekankan kepada keaktifan siswa dalam proses pembelajaran, dimulai dar pembentukan kelompok oleh siswa, kemudian siswa mengamati permasalahan, mencari sumber relevan yang dapat digunakan untuk memecahkan permasalahan, kemudian peserta didik mencoba memecahkan permasalahan dengan diskusi dalam kelompok yang telah dibentuk. Pembelajaran seperti ini lebih efektif dari pada pembelajaran konvensional dimana peserta didik hanya menulis danmendengar apa yang diterangkan oleh guru, jika peserta didik melakukan pengamatan langsung daya ingatnya pun akan lebih lama. Sehingga sangat berpengaruh terhadap hasil belajar peserta didik.

\subsection{Kontekstual}

Melalui pembelajaran kontektual peserta didik memiliki wawasan modernisasi islam sesuai dengan perkembanagn zaman [20]. Pembelajaran menggunakan kontektual mebantu guru melakukan pembelajaran bersama siswa dengan cara memberikan materi yang sesuai dengan kehidupan sehari-hari siswa, sehingga ada kaitan antara ilmu yang diberikan dengan penerapannya dalam kehidupan sehari-hari, jika dikaitkan dengan modernisasi islam, maka yang dapat dilakukan guru adalah diskusi dalam kelompok, studi kasus terkait modernisasi islam, pemutaran film pendek yang terkait dengan modernisasi islam, jika hal tersebut dilakukan dnegan benar maka wawasan keislaman peserta didik akan meningkat.

\subsection{Bervariasi}

Motivasi merupakan dorongan bagi peserta didik agar memiliki semangat dalam mengikuti proses pembelajaran, namun bagaimana semangat tersebut akan muncul jika guru masih menggunakan metode yang konvensional, metode konvensional biasanya hanya menggunakan metode ceramah, dalam artian guru menenrangkan dan siswa hanya mendengar dan mancatat. tentu harus menggunakan metode yang bervariasi agar peserta didik tidak jenuh dalam mengikuti proses pembelajaran. Penggunaan metode bervariasi dapat meningkatkan motivasi belajar siswa [21].

\subsection{Think Talk Write}

Penggunaan metode think talk write mampu meningkatkan konsep pemahaman siswa mengenai suatu materi PAI [22]. Metode ini dimulai dari peserta didik diberikan suatu permasalahan, kemudian mendiskusikan masalah tersebut dengan teman kelompoknya, setelah itu peserta didik menuliskan hasil disuksi dengan bahasa sendiri, dengan kegiatan yang terencana seperti itu membuat pemahaman peserta didik lebih meningkat dari sebelumnya. 


\subsection{Integrasi Nilai-nilai Multikultural}

Pendidkan agama islam merupakan pendidikan penting dan perlu dikenalkan, dalam upaya pengenalan dapat menggunakan integrasi nilai-nilai multicultural [23]. Nilai-nilai multikultural diantaranya adalah gaya hidup yang rukun toleransi, dan kerjasama, ada beberapa cara yangd apat digunakan dalam mengintegrasikan nilai-nilai-nilai multikultural, yaitu :

1. Diintegrasikan kedalam materi pembelajaran, dengan dimasukkan kedalam kurikulum yang dilakukan, kemudian menganalisi tema dan digabungkan dengan tema-tema.

2. Diintegrasikan kedalam metode pembelajaran, yang perl dilakukan guru adalah menggunakan metode disukusi, proyek dan kerjasama yang diharapkan dapat menjadikan siswa saling menghormati dna menhargai.

3. Diintegrasikan kedalam media pembelajaran, media merupakan perantara dalam pembelajaran yang diharapkan dapat membantu peserta didik dalam meningkatkan pemahaman peserta didik. Media yag digunakan tentu berhubungan erat dengan multikultural, media yang digunakan berupa, poster, gambar, video dan alat peraga.

\subsection{Tutor Sebaya}

Penggunaan metode tutor sebaya dan team kuis bermanfaat bagi pemahaman peserta didik mengenai PAI [24]. Penggunaan metode tutor sebaya dimulai dengan pembentuka kelompok yang terdiri dari beberapa orang peserta didik, kemudian salah satu dari peserta didik menjadi penyampai materi, sedangkan yang lainnya mendengarkan maeri yang disampaikan, metode ini akan berhasil apabila guru mampu memilih peserta didik yang menjadi tutor dengan baik, syarat menajdi tutor adalah, cerdas, berpenampilan rapi, dan mampu berkomunikasi dengan baik.

\subsection{Pendidikan Pluralisme}

Metode pendidikan pluralisme dapat memberikan pengatahuan bahwa harus memiliki sikap menghromati antar agama [25]. Tentu sangat bermanfaat jika guru menggunakan metode ini, metode pluralisme dimulai dari kontribusi, pengayaan,, mengambil keputusan dan aksi sosial. Pada bagian kontribusi peserta didik diinta menguasai materi dai keyakinan agamanya, kemudian dan kemudian memahami perbedaan budaya. Kemudian pada bagian pengayaan adalah guru melakykan integrasi pemahaman apresiasi beda agama dalam materi pembelajaran. setelah melaukan kontribusi dan pengayaan peserta didik tinggal melakukan yang telah diapahami yaitu mengambil keputusan dan melakukan aksi social.

\subsection{STAD}

Pengunaan metode STAD pada pembelajaran dan seluruh komponen STAD dilakukan maka akan mempengaruhi terhadap hasil belajar peserta didik [26]. Metode stad merupakan persaingan antar kelompok peserta didik. Sehingga peserta didik lebih bersemangat dan terpacu dalam mengikuti pembelajaran. pembelajaran yang demikian membuat pesera didik tidak merasa bosan danselalu merasa nyaman dalam keaktifan kelas yang dipmpin oleh guru yang menggunakan model tipe STAD.

\subsection{Head Together}

Implementasi metode pembelajaran numbered head together pada mater pendidikan agama islam sangat efektif dilakukan [27]. Metode ini dimulai ketika guru memberikan nomor paa kepala peserta didik yang merupakan ketua dalam kelompok, setelah itu guru akan memeberikan sebuah peranyaan, melalui pertanyaan tersbeut peserta diminya berfikir bersama dalam kelompok.

\subsection{Inquiry Based Learning}

Penggunaan metode inquiry based learning mmebuat suasan beajar PAI menjadi menyenangkan dan peserta didik aktif [28]. Metode ini memiliki tujuan agar peserta didik memahami bagaimana caranya belajar, dimana seorang gur menjadi fasilitator dan kemudian mampu membuat kelas tampak lebih nyaman dan tidak jenuh, jika peserta didik sudah paham bagaimana caranya belajar dengan tepat tentu guru akan lebih mudah dalam menyampaikan materi.

\subsection{Market Place}

Penggunaan metode masrket place dalam pembelajaran PAI bermanfaat bagi peserta didik [29]. Metode market place merupakan sebuah cara mengimplementasikan metode PAIKEM kedalam pembelajaran, PAIKEM adalah pembelajaran aktif, inovatif, kreatif, dan menyenangkan

\subsection{Komunikasi dari Guru}

Siswa yang mengalami kesulitan belajar harus ada tidnakan dari guru agar kembali bersemnaat 
belajar dengan caar menggunakan variasi dalam metode belajar [30, 31].

\section{KESIMPULAN}

Pendidikan agama islam merupakan salah satu matapelajaran yang penting untuk dikembangkan,, karena melalui pendidikan agama peserta didik lebih menjadi seseorang yang beretika, pendidikan agama perlu tersampaikan dengan kepada peserta didik, supaya tersampaikan dengan baik kepada peserta didik, guru perlu berfikir menegnai metode yang efektif untuk melakukan pembelajaran yang menyenangkan dan tidak membosankan bagi peserta didik.

\section{UCAPAN TERIMA KASIH}

Saya mengucapkan ribuan terimakasih kepada semua pihak yang telah membantu saya dalam hal melakukan penelitian ini. Selajutnya saya juga terimakasih telah diberikan dukungan dalam menyelesaikan penelitian ini

\section{REFERENSI}

[1] Amin, A., Wiwinda, W., Alimni, A., \& Yulyana, R, "Pengembangan Materi Pendidikan Agama Islam Berbasis Model Pembelajaran Inquiry Training Untuk Karakter Kejujuran Siswa Sekolah Menengah Pertama,” At-Ta'lim: Media Informasi Pendidikan Islam, vol. 17, no. 1, pp, 151-160, 2018.

[2] Alimni, A, “Analisis Sosiologi Perubahan Kurikulum Madrasah 2013,” At-Ta'lim: Media Informasi Pendidikan Islam, vol. 17, no. 2, pp, 181-190, 2018.

[3] Mubin, F “Kajian Literatur Pendidikan Agama Islam di SMA dan Perguruan Tinggi, pp, 1-8, 2020.

[4] Rohima, S, "Peran Pendidikan Agama Islam Dalam Era Industri 4.0," ITTIHAD, vol. 4, no. 1, pp 62-71, 2020.

[5] Araniri, N, "Peran Guru Pendidikan Agama Islam Dalam Menanamkan Sikap Keberagamaan Yang Toleran," Risâlah, Jurnal Pendidikan dan Studi Islam, vol. 6, no. 1, pp 54-65, Maret 2020.

[6] Amin, A, "Pemahaman Konsep Abstrak Ajaran Agama Islam pada Anak Melalui Pendekatan Sinektik dan Isyarat Analogi dalam Alquran,” MADANIA: JURNAL KAJIAN KEISLAMAN, vol. 21, no.2, pp 157-170, 2017

[7] Sa'diyah, H., Sholikhudin, M. A., \& Sholihun, M, "Pendampingan Model Pengelolaan Kelas Dalam Pembelajaran Pai Di Sd Riyadlul Arkham Tembong Plintahan Pandaan,” Khidmatuna: Jurnal Pengabdian Kepada Masyarakat, vol. 1, no. 1, pp, 47-62, 2020.

[8] Oktari, W., Harmi, H., \& Wanto, D, "Strategi Guru Dalam Pembelajaran Pai Pada Anak Berkebutuhan Khusus," TA'DIBUNA: Jurnal Pendidikan Agama Islam, vol. 3, no. 1, pp 13-28, 2020.

[9] Amin. A, "Pengembangan bahan ajar PAI pokok bahasan aspek akidah berbasis pembelajaran metafora dalam meningkatkan pemahaman konsep siswa SMP N 17 kota bengkulu," MANHAJ :Jurnal penelitian dan pengabdian masyarakat, vol. 3, no. 1, pp. 31-50, 2018.

[10] Alimni, A, "Penerapan Pendekatan Deepdialogue And Critical Thingking (Dd\&Ct) Untuk Meningkatkan Mutu Proses Dan Hasil Belajar Pai Siswa Kelas Viii Smpn 20 Kota Bengkulu,” Annizom, vol. 2, no. 2, pp 229-240, 2017.

[11] Lubis, M., Amin, A., \& Alimni, A, "Partisipasi Komite Sekolah Dalam Pencapaian Efektivitas Manajemen Sekolah Dasar," At-Ta'lim: Media Informasi Pendidikan Islam, vol. 18, no. 2, PP 359-372, 2019.

[12] Amin, A., \& Alimni, A, "Development of Religion Materials Based on Synectic Approach to Junior High School Students," At-Ta'lim: Media Informasi Pendidikan Islam, vol. 18, no. 1, pp 1-26, 2019.

[13] Alimni, "Globalisasi sebagai keniscayaan dan reorientasi pendidikan pesantren," At-ta'lim, vol. 16, no. 2, pp, 289307, 2017.

[14] Alimni, "Peradaban pendidikan gerakan intelektual masa abbasiyah,” At-Ta'lim, vol. 13, no. 2, pp, 333-346, 2014.

[15] Lismarwan, N. G., \& Nashori, F., "Proses Kreatif Pelukis Kaligrafi Islam: Sebuah Penelitian Kualitatif," Proyeksi: Jurnal Psikologi, vol. 5, no. 1, pp 1-16, 2020.

[16] Mukhliso, M, "Strategi guru pendidikan agama Islam untuk menanamkan pendidikan karakter religius di sekolah dasar," Jurnal Pendidikan Agama Islam Indonesia, vol. 1, no. 1, pp 64-68, 2020.

[17] Safrizal, M, "Konsepsi pola pendidikan agama Islam menurut Surat Luqman dan Hadits Tarbawi dalam mewujudkan Akhlaqul Karimah,” Jurnal Pendidikan Agama Islam Indonesia, vol. 1, no. 1, pp 48-63, 2020.

[18] Alamsyah, E., \& Ahwa, D. F, "Implementasi Metode Joyfull Learning pada Pembelajaran Pendidikan Agama Islam di Sekolah Menengah Pertama Alam Banyuwangi Islamic School,” AL-ADABIYAH: Jurnal Pendidikan Agama Islam, vol. 1, no. 1, pp 59-76, 2020.

[19] Primadoniati, A, "Pengaruh Metode Pembelajaran Problem Based Learning Terhadap Peningkatan Hasil Belajar Pendidikan Agama Islam,” Didaktika: Jurnal Kependidikan, vol. 9, no. 1, pp 77-87, 2020. 
[20] Winata, K. A., Solihin, I., Ruswandi, U., \& Erihadiana, M, "Moderasi Islam Dalam Pembelajaran PAI Melalui Model Pembelajaran Kontekstual," Ciencias: Jurnal Penelitian Dan Pengembangan Pendidikan, vol. 3, no. 2, pp 89-92, 2020.

[21] Nobisa, Y. N, "Penggunaan Metode Bervariasi Untuk Meningkatkan Motivasi Belajar Siswa Pada Pembelajaran Pendidikan Agama Islam,” Al Manar: Jurnal Pendidikan Islam, vol. 2, no. 1, pp 73-84, 2020.

[22] Supriatna, N, "Penerapan Metode Pembelajaran Think Talk Write Untuk Meningkatkan Pemahaman Konsep Siswa Pada Materi Mengonsumsi Makanan Dan Minuman Yang Halal Dan Menjauhi Yang Haram Di SMP Negeri 3 Ciawigebang," Syntax Idea, vol. 2, no. 3, pp, 61-67, 2020.

[23] Mustafida, F, "Integrasi Nilai-nilai Multikultural dalam Pembelajaran Pendidikan Agama Islam (PAI)," Jurnal Pendidikan Islam Indonesia, vol. 4, no. 2, pp, 173-185, 2020.

[24] Nurjanah, S., Yahdiyani, N. R., \& Wahyuni, S, "Analisis Metode Pembelajaran Akidah Akhlak dalam Meningkatkan Pemahaman dan Karakter Peserta Didik," EduPsyCouns: Journal of Education, Psychology and Counseling, vol. 2, no. 1, pp, 366-377. 2020.

[25] Saihu, M. M., \& Aziz, A, "Implementasi Metode Pendidikan Pluralisme Dalam Mata Pelajaran Pendidikan Agama Islam,” Belajea; Jurnal Pendidikan Islam, vol. 5, no. 1, pp 131-150, 2020.

[26] Setiawan, A., \& Sholeh, M. M. A, "Implementasi Model Pembelajaran Kooperatif Tipe STAD (Student Team Achievement Divisions) Dalam Pembelajaran Pendidikan Agama Islam (PAI)., " Prosiding Konferensi Ilmiah Mahasiswa Unissula (KIMU) Klaster Humanoira., 2020.

[27] Qomariyah, L., Tjahjono, A. B., \& Makhsun, T, "Implementasi Metode Pembelajaran Numbered Head Together (Nht) Dalam Pembelajaran PAI, Prosiding Konferensi Ilmiah Mahasiswa Unissula (KIMU) Klaster Humanoira, 2020.

[28] Utomo, W. B, “Aplikasi Pembelajaran Pai (Pendidikan Agama Islam) Metode Ibl (Inquiry Based Learning) Berbasis Zone Activity Di Sekolah Dasar Lebah Putih Salatiga,” Profetika: Jurnal Studi Islam, vol. 21, no. 1, pp. 99-108, 2020.

[29] Malihah, I., \& Ihsan, M. N, "Pengembangan Metode Market Place dalam Pembelajaran PAI," Atthulab: Islamic Religion Teaching and Learning Journal, vol. 5, no. 1, pp. 56-70, 2020.

[30] Nusroh, S., \& Luthfi, E, “Analisis Kesulitan Belajar Pendidikan Agama Islam (PAI) Serta Cara Mengatasinya," Belajea; Jurnal Pendidikan Islam, vol. 5, no. 1, pp, 71-92, 2020.

[31] Azhary, S. A., et al. "Relationship Between Behavior of Learning and Student Achievement in Physics Subject." Jurnal Pendidikan Fisika Indonesia, vol. 16, no. 1, pp. 1-8, 2020. 